\title{
ВПЛИВ ТЕХНОЛОГІЇ УТРИМАННЯ НА ПРОДУКТИВНІСТЬ ПІДСИСНИХ СВИНОМАТОК
}

\author{
Лихач Вадим Ярославович \\ доктор сільськогосподарських наук, доцент \\ Національний університет біоресурсів і природокористування України \\ ORCID: /0000-0002-9150-6730 \\ E-mail: lykhach80@ukr.net \\ Лихач Анна Василівна \\ доктор сільськогосподарських наук, доцент \\ Національний університет біоресурсів і природокористування України \\ ORCID: 0000-0002-0472-6162 \\ E-mail: avlykhach@gmail.com \\ Фаустов Ростислав Вікторович \\ аспірант кафедри технології виробництва продукції тваринництва \\ Миколаївський національний аграрний університет \\ ORCID: 0000-0003-2732-4032 \\ E-mail: svalker2013@gmail.com \\ Трибрат Руслан Олександрович \\ кандидат сільськогосподарських наук, доцент \\ Миколаївський національний аграрний університет \\ ORCID: 0000-0002-6710-570X \\ E-mail: tribrat21@ukr.net \\ Кисельова Світлана Олегівна \\ аспірант кафедри технології виробництва продукції тваринництва \\ Миколаївський національний аграрний університет \\ ORCID: 0000-0002-7685-5211 \\ E-mail: kisvol1990@gmail.com
}

Інтенсивне виробництво продукції свинарства висуває нові підвищені вимоги до технологічних особливостей ведення галузі свинарства. В останні роки в промисловому свинарстві поряд із загальним підвищенням інтенсивності виробництва відзначається загострення низки проблем (зниження збереженості молодняку, збільшення кількості аварійних опоросів, зниження продуктивності молодняку тощо). Для подолання цих негативних тенденцій потрібна розробка нових інтенсивно-технологічних рішень з питань створення оптимальних умов утримання на свинокомплексах. $B$ умовах сьогодення виникають дискусії, щодо виду розташування фіксуючого станку для свиноматки в боксі опоросу: діагональне чи пряме? Але як пряме розташування клітки, так і діагональне мають згідно з дослідженнями свої переваги і недоліки. Отже, метою досліджень було вивчення продуктивності підсисних свиноматок та поросят-сисунів залежно від розташування фріксуючих станків в боксі для опоросу (діагональне чи пряме). Дослідження були проведенні в умовах СВК «Агрофрірма «Миг-Сервіс-Агро» Новоодеського району Миколаївської області на поголів'ї чистопородних свиноматок породи ландрас та матках внутрішньопородного типу свиней породи дюрок української селекції «Степовий». В цеху опоросу було відведено по два блоки опоросу по 8 боксів для опоросу свиноматок з прямим розташуванням фріксуючого станку - I та II контрольні групи та по два блоки опоросу по 8 боксів для опоросу свиноматок з діагональним розташуванням фіксуючого станку - III та IV дослідні групи, а інші технологічні фрактори утримання піддослідних груп були ідентичними. Вивчення продуктивних якостей піддослідних тварин проводили за загальноприйнятими методичними рекомендаціями. Доведено, що розташування фріксуючого станку для свиноматки в боксі опоросу впливає на показники їх відтворювальних ознак. Пряме розташування фріксуючого станку для опоросу, на відміну від діагонального, зумовило підвищення кількості поросят при відлученні - на 0,6 ка (P>0,95); збереженості - 5,1\% (P>0,99); вирівняності гнізда при відлученні - на 25,0\% $(P>0,99)$. Водночас не встановлено впливу на показники багатоплідності, великоплідності та молочності. Отримані результати визначають перспективність подальших досліджень.

Ключові слова: технологія, свиноматка, цех опоросу, фріксуючий станок, відтворювальні якості.

DOI: https://doi.org/10.32845/bsnau.Ivst.2019.1-2.11

Рівень життя населення тісно пов'язаний із розвитком галузей тваринництва, частка якого в структурі продовольства становить понад 45\%, зокрема галузь свинарства займає близько 40\%, у забезпечені населення м'ясною продукцією. Вартість свинини знаходиться на третьому місці

після ягнятини та яловичини, а за своїми поживними й кулінарними перевагами свинині належить перше місце 3поміж іншої м'ясної продукції. Важливою складовою частиною технології виробництва продукції свинарства, від якої залежить подальший прогрес галузі є впровадження інтен-

Вісник Сумського національного аграрного університету 
сивних технологій, які використовують високопродуктивні генотипи, повнораціонну годівлю, високотехнологічне обладнання для утримання і годівлі свиней, гноєвидалення, вентиляції тощо $[2,3,11,14]$.

Необхідною умовою подальшого розвитку свинарства в Україні $є$ прискорений перехід на виробництво конкурентоспроможної м'ясної свинини. Інтенсивне виробництво продукції свинарства висуває нові підвищені вимоги до технологічних особливостей ведення галузі. В останні роки в промисловому свинарстві поряд із загальним підвищенням інтенсивності виробництва відзначається загострення низки проблем (зниження збереженості молодняку, збільшення кількості аварійних опоросів, зниження продуктивності молодняку тощо). Для подолання цих негативних тенденцій потрібна розробка нових інтенсивно-технологічних рішень 3 питань створення оптимальних умов утримання, годівлі та системи селекційно-племінної роботи на малих, середніх та великих свинокомплексах [2, 3, 5, 10, 14].

Визначено, що на сьогодні частина свинарських підприємств створюються на основі реконструкції різних за напрямом використання тваринницьких об'єктів, що в свою чергу обумовлює особливості організації та проектування окремих цехів і блоків виробництва свинини $[7,8,10]$.

Блок для опоросу $є$ не тільки найдорожчою будовою в цеху для свиноматок, але і дуже важливим. Він повинен забезпечувати комфорт для свиноматки та для новонароджених поросят і в той же час бути зручним для персоналу при проведенні процедур з утримання та догляду. Призначенням блоку для опоросу є вихід якомога більшої кількості поросят з високою масою при відлученні. Звичайно, технологія $€$ лише однією частиною цього завдання, а температурний режим та догляд, безпосередньо генотип тварин також відіграють важливу роль $[1,4,12]$.

Відповідність біологічним потребам поросят і свиноматок $€$ основоположним при проектуванні блоку для опоросу. У всьому світі бокс для опоросу $є$ найбільш поширеним вирішенням даної проблеми. Якість, міцність, ціна і ефективність - основні складові станків для опоросу. Тривалий час i, навіть, в умовах сьогодення виникають дискусії, щодо виду розташування фіксуючого станку для свиноматки в боксі опоросу: діагональне чи пряме? Але як пряме розташування клітки, так і діагональне мають згідно з дослідженнями свої переваги і недоліки. Оптимальними на сьогоднішній день вважаються бокси довжиною від 2,4 до 2,5 м при ширині 1,7-1,9 м. При діагональному розташуванні свиноматки в загоні його довжина може бути зменшена на 10-20 см $[3,8,15]$.

Враховуючи цей фракт та постійну дорожнечу будівельних матеріалів, нами було поставлене завдання щодо проведення аналізу впливу розташування фріксуючих станків для підсисної свиноматки в боксі для опоросу (діагональне чи пряме) на їх відтворювальні якості. В контексті зазначених вимог і сформована наша мета досліджень та визначена її актуальність.

Мета досліджень - вивчення продуктивності підсисних свиноматок та поросят-сисунів залежно від розташування фіксуючих станків в боксі для опоросу (діагональне чи пряме).

Матеріали та методи досліджень. Вивчався вплив інтенсивних технологічних рішень на відтворювальні якості свиноматок в цеху опоросу. У науково-господарському досліді вивчалися відтворювальні якості свиноматок залежно від породи та розташування фіксуючого станку в боксі для опоросу, згідно схеми досліджень наведеної в таблиці 1.

Таблиця 1

Схема досліду з вивчення відтворювальних якостей свиноматок залежно від розташування фіксуючого станку в боксі для опоросу та генотипу

\begin{tabular}{|c|c|c|c|c|}
\hline Група & Призначення груп & Порода & Кількість тварин, гол. & $\begin{array}{c}\text { Розташування фіксуючого станку в боксі для } \\
\text { опоросу }\end{array}$ \\
\hline I & \multirow[b]{2}{*}{ контрольна } & $\Omega^{1}$ & 16 & \multirow{2}{*}{ Пряме } \\
\hline II & & ДУСС2 & 16 & \\
\hline III & \multirow{2}{*}{ дослідна } & $\pi$ & 16 & \multirow{2}{*}{ Діагональне } \\
\hline IV & & ДУСС & 16 & \\
\hline
\end{tabular}

Дослідження були проведенні в умовах СВК «Агрофрірма «Миг-Сервіс-Агро» Новоодеського району Миколаївської області на поголів"ї чистопородних свиноматок породи ландрас та матках внутрішньопородного типу свиней породи дюрок української селекції «Степовий». В цеху опоросу було відведено по два блоки опоросу по 8 боксів (16 + 16 місць) для опоросу свиноматок з прямим розташуванням фіксуючого станку - I та II контрольні групи (рис. 1) та по два блоки опоросу по 8 боксів (16 + 16 місць) для опоросу свиноматок з діагональним розташуванням фіксуючого станку III та IV дослідні групи (рис. 2), а інші технологічні фактори утримання піддослідних груп були ідентичними.

Відтворювальні якості свиноматок визначали за по- казниками: багатоплідності, живої маси кожного поросяти при народженні та відлученні (28 днів), умовної молочності, кількості поросят в гнізді при відлученні, збереженості приплоду та вирівняності гнізда при відлученні (за формулою Клеміна-Павлова). Умови годівлі та утримання піддослідних тварин були ідентичними та відповідали нормативним вимогам. Вивчення продуктивних якостей піддослідних тварин проводили за загальноприйнятими методичними рекомендаціями. Для вивчення й підтвердження сили впливу фракторів на досліджувану ознаку був проведений двофакторний дисперсійний аналіз за допомогою моделі Г. Шефффе [6, 9, $13,14]$. 


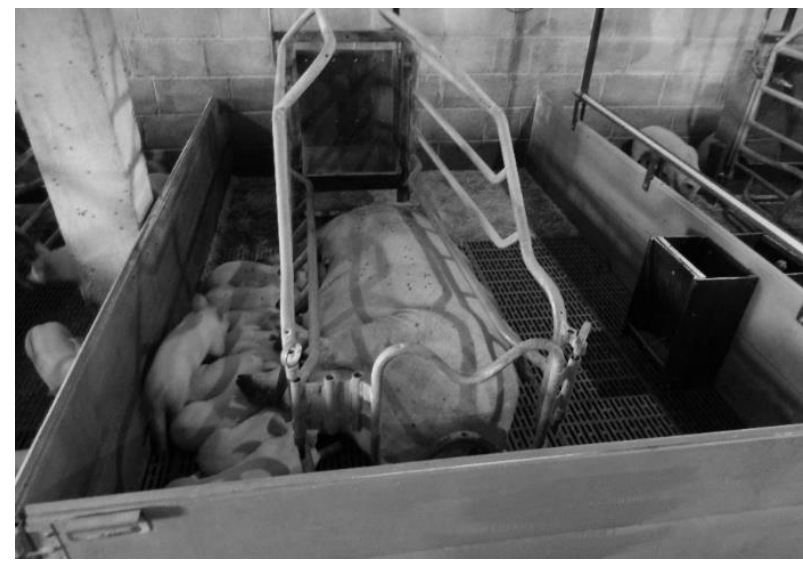

Puc. 1. Пряме розташування фіксуючого станку (фото автора)

Результати досліджень. Показники відтворювальних якостей свиноматок піддослідних груп залежно від

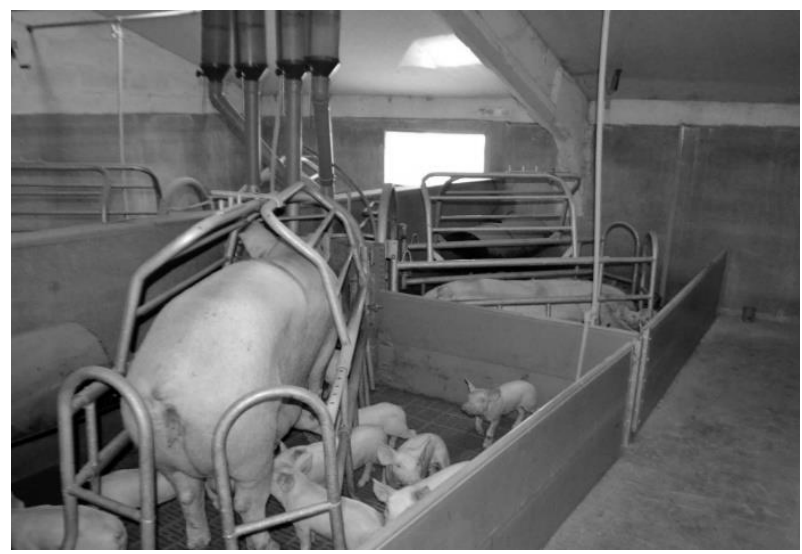

Puc. 2. Діагональне розташування фіксуючого станку (фото автора)

розташування фіксуючого станку в боксі для опоросу та породи маток представлені в таблиці 2.

Таблиця 2

Відтворювальні якості свиноматок залежно від розташування фіксуючого станку в боксі для опоросу та генотипу, $\bar{X} \pm S_{\bar{X}}$

\begin{tabular}{|c|c|c|c|c|c|c|c|c|}
\hline \multicolumn{2}{|c|}{ Група тварин } & \begin{tabular}{|c|}
$\begin{array}{c}\text { Багатоплідність, } \\
\text { гол. }\end{array}$ \\
\end{tabular} & $\begin{array}{c}\begin{array}{c}\text { Великоплідність, } \\
\text { кг }\end{array} \\
\end{array}$ & \begin{tabular}{|c|} 
Молочність, \\
кг \\
\end{tabular} & $\begin{array}{c}\text { Кількість поросят при } \\
\text { відлученні у } 28 \text { днів, гол. }\end{array}$ & $\begin{array}{c}\text { Жива маса поросяти при } \\
\text { відлученні, кг }\end{array}$ & $\begin{array}{c}\text { 3береженість, } \\
\% \\
\end{array}$ & \begin{tabular}{|c|} 
Вирівняність гнізда при \\
відлученні, балів
\end{tabular} \\
\hline \multicolumn{9}{|c|}{ Контрольні групи (прямий фіксуючий станок), (n=16) } \\
\hline I & $\begin{array}{l}\text { ○ } \\
\text { Л }\end{array}$ & $\begin{array}{c}12,1 \\
\pm 0,30\end{array}$ & $\begin{array}{c}1,40 \\
\pm 0,02\end{array}$ & $\begin{array}{c}64,6 \\
\pm 2,80\end{array}$ & $\begin{array}{r}11,5 \\
\pm 0,24\end{array}$ & $\begin{array}{c}8,0 \\
\pm 0,22\end{array}$ & $\begin{array}{c}94,2 \\
\pm 1,62\end{array}$ & $\begin{array}{c}66,9 \\
\pm 3,00\end{array}$ \\
\hline II & $\begin{array}{l}\text { क дУСС } \\
\times \text { के дУСс }\end{array}$ & $\begin{array}{r}10,6 \\
\pm 0,24\end{array}$ & $\begin{array}{r}1,41 \\
\pm 0,02 \\
\end{array}$ & $\begin{array}{c}54,8 \\
\pm 3,20\end{array}$ & $\begin{array}{c}10,1 \\
\pm 0,30\end{array}$ & $\begin{array}{r}8,1 \\
\pm 0,18 \\
\end{array}$ & $\begin{array}{r}94,6 \\
\pm 2,00\end{array}$ & $\begin{array}{r}48,4 \\
\pm 2,44 \\
\end{array}$ \\
\hline \multicolumn{9}{|c|}{ Дослідні групи (діагональний фіксуючий станок), (n=16) } \\
\hline III & 申 Л×ठ & $\begin{array}{c}12,0 \\
\pm 0,48\end{array}$ & $\begin{array}{r}1,38 \\
\pm 0,04\end{array}$ & $\begin{array}{c}60,3 \\
\pm 3,60\end{array}$ & $\begin{array}{c}10,8 \\
\pm 0,28^{*}\end{array}$ & $\begin{array}{c}7,4 \\
\pm 0,20^{*}\end{array}$ & $\begin{array}{c}90,0 \\
\pm 1,40^{*}\end{array}$ & $\begin{aligned} & 54,2 \\
\pm & 2,84^{* *}\end{aligned}$ \\
\hline IV & $\begin{array}{l}\text { क ДУСС } \\
+ \text { дУ ДУСС }\end{array}$ & $\begin{array}{c}10,7 \\
\pm 0,26\end{array}$ & $\begin{array}{r}1,40 \\
\pm 0,03\end{array}$ & $\begin{array}{c}51,8 \\
\pm 2,24\end{array}$ & $\begin{array}{c}9,2 \\
\pm 0,26^{*}\end{array}$ & $\begin{array}{c}7,5 \\
\pm 0,20^{*}\end{array}$ & $\begin{array}{c}88,6 \\
\pm 1,80^{\text {** }}\end{array}$ & $\begin{aligned} & 33,3 \\
\pm & 2,26^{\text {***}}\end{aligned}$ \\
\hline
\end{tabular}

Примітки: ${ }^{*}-P>0,95 ;{ }^{* *}-P>0,99 ;{ }^{* * *}-P>0,999$

Аналізуючи показники відтворювальних якостей свиноматок породи ландрас та внутрішньопорідного типу свиней породи дюрок української селекції «Степовий», які протягом підсисного періоду утримувалися в боксах для опоросу з різним розташуванням фіксуючого станку відмічаємо, що за показником багатоплідності, великоплідності та молочності не встановлено вірогідної різниці між групами.

Протягом досліджень, спостерігаючи за тваринами було відмічено, що при очищенні боксів для опоросу з діагональним розташуванням фіксуючого станку виникали труднощі з очищенням дальньої зони. Оператору цеху опоросу не рідко приходилося заходити у бокс для ретельного його очищення, подібних ситуацій майже не виникало при прямому розташуванні фіксуючого станку. Крім того, у випадку придавлювання свиноматкою поросят конструктивними елементами станку, операторам зручніше було «рятувати» поросят при прямому розташуванні станку, тобто доступ до тварини був більшим. Перераховані факти в певній мірі впливали на показники збереженості та енергії росту пороСЯт.

Кількість поросят при відлученні у свиноматок породи ландрас, які утримувалися в діагональних фіксуючих станках становила 10,8 голів, що на 6,5\% менше за аналогів, які утримувалися в прямих фріксуючих станках, де для свиноматок внутріпорідного типу різниця за цим показником становила 9,8\% на користь контрольної групи ( $>>0,95)$.

Протягом досліджень також спостерігалося, що в прямих фіксуючих станках свиноматки «зручніше» розміщалися в плані доступності сосків для поросят у процесі годівлі, не впираючись ними в елементи конструкції станку, на відміну від діагонального розташування фіксуючого станку. Жива маса поросят при відлученні була вищою у поросят контрольних груп, і вірогідно перевищувала дослідні групи на 0,6 кг ( $P>0,95)$.

Пряме розташування фіксуючого станку для опоросу зумовило отримання вищого значення показнику збереженості у свиноматок породи ландрас - 94,2\%, у свиноматок внутрішньопородного типу свиней породи дюрок української селекції «Степовий» - 94,6\%, що відповідно на 4,2\% та $6 \%$ більше за аналогів, які утримувалися в станках з діагональним розташуванням ( $P>0,95 ; P>0,99)$ відповідно.

Важливою вимогою при відлученні поросят є отримання вирівняних гнізд, адже поросята, які різко відрізняються у розвитку від середнього по гнізду в подальшому у процесі вирощування будуть гірше відгодовуватися та оплачувати корми приростами. Натомість, більш вирівняними при відлученні були гнізда поросят I та II контрольних груп (пряме розташування фіксуючого станку), які вірогідно переважали аналогів III та IV дослідних груп (діагональне розташування фіксуючого станку) на 18,9\% та $31 \%$ відповідно ( $P>0,99 ; P>0,999)$.

3 метою підтвердження сили впливу фракторів (розташування фріксуючого станку для опоросу, генотипу) на досліджувану ознаку (показники відтворювальних якостей

Вісник Сумського національного аграрного університету 
свиноматок) в розрізі дослідних господарств був проведений двофакторний дисперсійний аналіз. Вплив розташування фіксуючого станку в боксі опоросу (фактор A) та генотипу свиноматки (фактор В) на відтворювальні якості наведено у таблиці 3.

За результатами досліджень встановлено, що залежність показнику багатоплідності свиноматок, в умовах СВК «Агрофрірма «Миг-Сервіс-Агро» Миколаївської області від досліджуваних факторів, має вірогідність від другого фактора (генотип свиноматки) на рівні 22,65\% і взагалі відсутній вплив розташування фіксуючого станку на даний показник, тоді як взаємодія обох оцінених факторів виявляється значно нижчою, ніж власне самі фрактори - 0,12\%.

За результатами аналізу досліджуваних фракторів не виявлено вірогідного впливу ні за типом розташування станку, генотипом свиноматок, ні сукупності обох факторів на показник великоплідності поросят.

Результати досліджень представлені у таблиці 3 вказують на те, що на показник молочності свиноматок в розрізі піддослідних груп, вірогідно впливає другий фактор
(B) - генотип $(13,12 \%)$.

При аналізі результатів досліджень встановлено, що на кількість поросят при відлученні більшу силу впливу має генотип свиноматки (ландрас чи внутрішньопорідний тип свиней породи дюрок української селекції «Степовий») 30,81\%. Також необхідно відмітити, що матки породи ландрас мали вищі показники відтворювальних якостей у порівняні з аналогами внутрішньопородного типу. Відмічено також вірогідний вплив розташування станку на досліджуваний показник - 8,76\%, при не значному сумісному впливі $0,14 \%$.

В більшій мірі на показник живої маси поросят при відлученні має сила впливу розташування фріксуючого станку в боксі опоросу - 12,94\%. Не відмічено вірогідного впливу генотипу (фактор В) на масу поросят при відлученні. Крім того, взагалі не виявлено сумісного впливу досліджуваних фракторів (табл. 3). Пряме розташування фріксуючого станку в боксі опоросу створює більш оптимальні умови для росту поросят.

Таблиця 3

Вплив розташування фіксуючого станку в боксі опоросу та генотипу свиноматки на відтворювальні якості

\begin{tabular}{|c|c|c|c|c|c|c|}
\hline Фактор & SS & $d f$ & $M S$ & $F$ & $p$ & $\eta^{2}, \%$ \\
\hline \multicolumn{7}{|c|}{ Сила впливу факторів на багатоплідність } \\
\hline Розташування станку (A) & 0,00 & 1 & 0 & 0,000 & 1,0000 & 0,00 \\
\hline Генотип (B) & 31,36 & 1 & 31,36 & 17,594 & 0,0001 & 22,65 \\
\hline$A \times B$ & 0,16 & 1 & 0,16 & 0,090 & 0,7655 & 0,12 \\
\hline Залишкова & 106,94 & 60 & 1,7824 & - & - & 77,23 \\
\hline Загальна & 138,46 & 63 & - & - & - & - \\
\hline \multicolumn{7}{|c|}{ Сила впливу факторів на молочність } \\
\hline Розташування станку (A) & 213,2 & 1 & 213,16 & 1,478 & 0,2289 & 2,09 \\
\hline Генотип (B) & 1339,6 & 1 & 1339,6 & 9,288 & 0,0034 & 13,12 \\
\hline$A \times B$ & 6,8 & 1 & 6,76 & 0,047 & 0,8293 & 0,07 \\
\hline Залишкова & 8653,8 & 60 & 144,23 & - & - & 84,72 \\
\hline Загальна & 10213,3 & 63 & - & - & - & - \\
\hline \multicolumn{7}{|c|}{ Сила впливу факторів на кількість поросят при відлученні } \\
\hline Розташування станку (А) & 10,2 & 1 & 10,24 & 8,719 & 0,0045 & 8,76 \\
\hline Генотип (B) & 36,0 & 1 & 36 & 30,654 & 0,0000 & 30,81 \\
\hline$A \times B$ & 0,2 & 1 & 0,16 & 0,136 & 0,7133 & 0,14 \\
\hline Залишкова & 70,5 & 60 & 1,174 & - & - & 39,71 \\
\hline Загальна & 116,9 & 63 & - & - & - & - \\
\hline \multicolumn{7}{|c|}{ Сила впливу факторів на масу поросят при відлученні } \\
\hline Розташування станку (A) & 5,8 & 1 & 5,76 & 8,955 & 0,0040 & 12,94 \\
\hline Генотип (B) & 0,2 & 1 & 0,16 & 0,249 & 0,6198 & 0,36 \\
\hline$A \times B$ & 0,0 & 1 & 0 & 0,000 & 1,0000 & 0,00 \\
\hline Залишкова & 38,6 & 60 & 0,6432 & - & - & 86,70 \\
\hline Загальна & 44,5 & 63 & - & - & - & - \\
\hline \multicolumn{7}{|c|}{ Сила впливу фракторів на збереженість поросят } \\
\hline Розташування станку (А) & 416,2 & 1 & 416,2 & 8,799 & 0,0043 & 12,72 \\
\hline Генотип (B) & 4,0 & 1 & 4 & 0,085 & 0,7722 & 0,12 \\
\hline$A \times B$ & 13,0 & 1 & 12,96 & 0,274 & 0,6026 & 0,40 \\
\hline Залишкова & 2837,9 & 60 & 47,3 & - & - & 13,24 \\
\hline Загальна & 3271,0 & 63 & - & - & - & - \\
\hline \multicolumn{7}{|c|}{ Сила впливу факторів на вирівняність гнізда при відлученні } \\
\hline Розташування станку (A) & 3091,4 & 1 & 3091,4 & 27,477 & 0,0000 & 19,23 \\
\hline Генотип (B) & 6209,4 & 1 & 6209,4 & 55,191 & 0,0000 & 38,63 \\
\hline$A \times B$ & 23,0 & 1 & 23,04 & 0,205 & 0,6525 & 0,14 \\
\hline Залишкова & 6750,4 & 60 & 112,51 & - & - & 42,00 \\
\hline Загальна & 16074,3 & 63 & - & - & - & - \\
\hline
\end{tabular}

У дослідних групах спостерігається нижче значення показнику збереженості - 88,6-90,0\%, у порівняні з аналогами контролю вони поступалися на 6,0-4,2\% відповідно. Для підвищення показнику збереженості, не зважаючи на генотип свиноматки, доцільніше використовувати пряме розташування фіксуючого станку в боксі опоросу. Так, сила впли- 
ву цього фактору на показник збереженості становить $12,72 \%$, при відсутності вірогідній силі впливу генотипу та сумісного впливу факторів.

За результатами досліджень встановлено, що за рахунок збільшення показників маси гнізда поросят при відлученні, кількості поросят при відлученні та зменшені кількості відстаючих поросят дало можливість отримати вищі значення показнику вирівняності гнізда поросят при відлученні у свиноматок, які протягом підсисного періоду утримувалися в прямих фріксуючих станках у боксі опоросу.

Так, сила впливу розташування станку на вирівняність гнізда при відлучені дорівнює - 19,23\%, сила впливу генотипу свиноматок на досліджуваний показник становить - 38,63\% (див. табл. 3).

За результатами досліджень встановлено, що пряме розташування фіксуючого станку для свиноматки в боксі опоросу, на відміну від діагонального розташування, сприяє підвищенню показників кількості та маси поросят при відлу- ченні, збереженості і, як наслідок, вирівняності гнізда при відлученні за рахунок створення більш оптимальних умов утримання підсисних свиноматок та поросят-сисунів.

Висновки і перспективи подальших досліджень. Доведено, що розташування фіксуючого станку для свиноматки в боксі опоросу впливає на показники їх відтворювальних ознак. Пряме розташування фріксуючого станку для опоросу, на відміну від діагонального, зумовило підвищення кількості поросят при відлученні - на 0,6 кг ( $\mathrm{P}>0,95)$; збереженості - 5,1\% (P>0,99); вирівняності гнізда при відлученні - на 25,0\% ( $P>0,99)$. Водночас не встановлено впливу на показники багатоплідності, великоплідності та молочності. Отримані результати визначають перспективність подальших досліджень.

Подяка. Робота виконана в рамках держбюджетної тематики Міністерства освіти і науки України (номер державної реєстрації 0119U001042).

\section{Список використаної літератури:}

1.Волощук В. М., Повод М. Г. Вплив умов утримання на репродуктивні якості свиноматок. Свинарство : міжвід. темат. наук. зб. Інституту свинарства і АПВ НААН України. Полтава., 2013. Вип. 62. С. 27-32.

2.Іванов С.С., Бородаєнко Ф.А., Топіха В.С., Лихач В.Я. Ефективне виробництво свинини в умовах СВК «Агрофірма «Миг-Сервіс-Агро». Вісник аграрної науки Причорномор'я. Миколаїв, 2015. Вип. 2 (84). Т. 2. С. 78-86.

3.Лихач В. Я. Обґрунтування, розробка та впровадження інтенсивно-технологічних рішень у свинарстві : монографія. Миколаїв : МНАУ, 2016. 227 с

4.Лихач В. Я. Відтворювальні якості свиноматок залежно від конструктивних особливостей станкового обладнання. Тваринництво України, 2015. № 8. С. 34-37.

5.Лоза А. А. Слагаемые успеха отечественного свиноводства. Тваринництво сьогодні, 2010. № 2. С. 18-20.

6.Методологія та організація наукових досліджень у тваринницті; за ред. І.І. Ібатуліна, О.М. Жукорського : посібник. К. :Аграрна наука, 2017. 328 с.

7.Повод М.Г., Гетьман В.В. Утримання та годівля холостих і поросних свиноматок. Пропозиція, 2007. № 8. С. 116-121.

8.Повышение продуктивности маточного стада свиней. [Г. С. Походня, А.И. Гришин, Р. А. Стрельников, Е. Г. Федорчук, В. В. Шабловский]. Белгород : «Константа», 2013. 488 с.

9.Проваторов Г.В., Проваторова В.А. Кормление сельскохозяйственных животных: учебник. Сумы : ИТД «Университетская книга», 2004. 510 c.

10. Ресурсосберегающие технологии производства свинины : теория и практика : учеб. пособие. А. Н. Царенко, О. В. Крятов, Р. Е. Крятов и др.; под ред. А. Н. Царенко. Сумы : ИТД «Университетская книга», 2004. 269 с.

11. Рыбалко В. П. Проблемы производства свинины в странах СНГ. Свиноводство, 2010. № 7. С. $48-49$.

12. Свинарство : монографія. [В. М. Волощук, В. П. Рибалко, М. Д. Березовський та ін.]. К. : Аграрна наука, 2014. 587

C.

13. Сучасні методики досліджень у свинарстві. Полтава, 2005. 228 с.

14. Технологія виробництва продукції свинарства: навчальний посібник. [В. С. Топіха, В. Я. Лихач, С. І. Луговий, Г. І. Калиниченко, О. А. Коваль, Р. О. Трибрат]. Миколаїв : МДАУ, 2012. 453 с.

15. Черненко А. В. Відтворювальні якості свиноматок при різних способах утримання. Вісник аграрної науки Причорномор'я. Миколаїв : МДАУ, 2006. Вип. 3(35). С. 85-88.

1.Voloshchuk, V.M., Povod, M.H., 2013. Vplyv umov utrymannia na reproduktyvni yakosti svynomatok [Influence of keeping conditions on the reproductive quality of sows]. Svynarstvo : mizhvid. temat. nauk. Zb. Instytutu svynarstva i APV NAAN Ukrainy. Poltava. issue 62, pp. 27-32.

2.Ivanov, S. S., Borodaienko, F. A., Topikha, V. S., Lykhach, V. Ya., 2015. Efektyvne vyrobnytstvo svynyny v umovakh SVK «Ahrofirma «Myh-Servis-Ahro» [Effective production of pork in the conditions of Agro Firm «MIG-Service-Agro»]. Visnyk ahrarnoi nauky Prychornomoria. Mykolaiv. issue. 2(84), v. 2, pp. 78-86.

3.Lykhach, V.Ya., 2016. Obgruntuvannia, rozrobka ta vprovadzhennia intensyvno-tekhnolohichnykh rishen u svynarstvi : monohrafiia [Substantiation, development and implementation of intensive technological solutions in pig production: monograph]. Mykolaiv : MNAU. 227 p.

4.Lykhach, V.Ya., 2015. Vidtvoriuvalni yakosti svynomatok zalezhno vid konstruktyvnykh osoblyvostei stankovoho obladnannia [Reproductive qualities of sows depending on the design features of the loom equipment]. Tvarynnytstvo Ukrainy. issue 8 , pp. 34-37.

5.Loza, A. A., 2010. Slahaembe uspekha otechestvennoho svynovodstva [Summaries of the success of domestic pig production]. Tvarynnytstvo sohodni. issue 2. pp. 18-20. 
6. Metodolohiya ta orhanizatsiya naukovykh doslidzhen $v$ tvarynnytsti [Methodology and organization of scientific research in animals] / za red. I. I. Ibatulina, O. M. Zhukorskoho. Posibnyk. Kyiv. : Ahrarna nauka, 2017. 328

7.Povod, M.H., Hetman, V.V., 2007. Utrymannia ta hodivlia kholostykh i porosnykh svynomatok [The maintenance and feeding of single and pregnant sows]. Propozytsiia. issue 8, pp. 116-121.

8.Povyshenye produktyvnosty matochnoho stada svynei [Increasing the productivity of broodstock] / [H.S. Pokhodnia, A.Y. Hryshyn, R.A. Strelnykov, E.H. Fedorchuk, V. V. Shablovskyi]. Belhorod : «Konstanta», 2013. 488.

9.Provatorov, H.V., Provatorova, V. A., 2004 Kormlenye selskokhoziaistvennykh zhyvotnykh: uchebnyk [Feeding farm animals: a textbook]. Sumy : YTD «Unyversytetskaia knyha». 510/

10. Resursosberehaiushchye tekhnolohyy proyzvodstva svynyny [Resource-saving technologies for pork production: theory and practice] / A. N. Tsarevych, O. V. Kriatov, R. E. Kriatov y dr.; pod red. A. N. Tsarenko. Sumy : YTD «Unyversytetskaya knyga», 2004, 269 .

11. Rybalko, V. P., 2010. Problemy proyzvodstva svynyny v stranakh SNH [Problems of pork production in the CIS countries ]. Svynovodstvo. issue 7, pp. 48-49.

12. Svynarstvo : monohrafiia [Pig farming: a monograph] / [V. M. Voloshchuk, V. P. Rybalko, M. D. Berezovskyi ta in.]. K. : Ahrarna nauka, 2014. 587.

13. Suchasni metodyky doslidzhen u svynarstvi [Current research methods in pig production]. Poltava, 2005. 228.

14. Tekhnolohiia vyrobnytstva produktsii svynarstva : navchalnyi posibnyk [Technology of pig production: a textbook] / [V. S. Topikha, V. Ya. Lykhach, S. I. Luhovyi, H. I. Kalynychenko, O. A. Koval, R. O. Trybrat]. Mykolaiv : MDAU, 2012. 453.

15. Chernenko A. V. Vidtvoriuvalni yakosti svynomatok pry riznykh sposobakh utrymannia [Reproductive qualities of sows with different methods of keeping]. Visnyk ahrarnoi nauky Prychornomoria. Mykolaiv : MDAU, 2006. issue. 3(35). pp. 85-88.

\section{Lykhach, V.Ya., \\ Lykhach, A.V., \\ Faustov, R.V., \\ Tribrat, R.O., \\ Kiseleva, S.O.}

The influence of retention technology on the performance of suckling sows

The intensive production of pig production puts new demands on the technological features of the pig industry. In recent years, in industrial pig breeding, along with the general increase in production intensity, there have been exacerbation of a number of problems (decrease in preservation of young animals, increase in the number of emergency farrows, decrease in productivity of young animals, etc.). To overcome these negative trends, it is necessary to develop new intensive technological solutions to create optimal conditions of confinement at the pig complexes. In today's context, there are discussions about the type of sowing machine location in a farrowing box: diagonal or straight? But both the direct location of the cell and the diagonal have, according to research, their advantages and disadvantages. Therefore, the purpose of the study was to investigate the performance of suckling sows and mammals depending on the location of the locking machines in the farrowing box (diagonal or straight). The studies were conducted under the conditions of Agro Firm «MIG-Service-Agro» of the Novoodeskiy region, Mykolaiv Oblast, on the stock of purebred sows of the Landras breed and the uterus of the domestic breed pigs of the Durok breed of the Ukrainian selection «Stepoviye». In the farrowing shop two blocks of 8 boxes were taken for farrowing of sows with direct location of the locking machine - I and II control groups and two blocks of farmering of 8 boxes for farrowing of sows with diagonal location of the locking machine - III and IV experimental groups, and III and IV experimental groups. Other technological retention factors of the study groups were identical. The study of productive qualities of experimental animals was carried out according to generally accepted methodological recommendations. It is proved that the location of the sowing machine in the farrowing box affects the performance of their reproductive characteristics. The direct location of the locking machine for farrowing, unlike the diagonal one, caused an increase in the number of piglets when weaned - by $0.6 \mathrm{~kg}(P>0.95)$; retention rate - 5.1\% ( $P>0.99)$; of the nest when weaned - by $25.0 \%$ ( $P>0.99)$. At the same time, no impact on the indicators of multiplicity, fertility and milk yield was established. The results obtained determine the prospects for further research.

Key words: technology, sow, farrowing shop, locking machine, reproductive qualities.

Дата надходження до редакиіі: 18.04.2019 p. 